\title{
Pilot Study on Molecular Quantitation and Sequencing of Endometrial Cytokines Gene Expression and their Effect on the Outcome of In-Vitro Fertilization (IVF) Cycle
}

\author{
Dina Sabry ${ }^{1}$, Samar Marzouk ${ }^{1}$, Amira Hassouna ${ }^{1}$, \\ Olfat Nouh ${ }^{2}$ and Hoda Abdel Aal ${ }^{2}$
}

Departments of Medical Biochemistry and Molecular Biology, Obstetrics and Gynaecology ${ }^{2}$, Faculty of Medicine, Cairo University, Egypt

\begin{abstract}
Background: Human trophoblast invasion and differentiation are essential for successful pregnancy outcome. The molecular mechanisms; however, are poorly understood. Interleukin (IL)-11, a cytokine that regulates endometrial epithelial cell adhesion, trophoblast motility and invasion during implantation, may be involved in some of these processes. Leukemia inhibitory factor (LIF) is one of the key cytokines in the embryo implantation regulation. The present study aimed to assess the levels of LIF, IL-11 and IL-11 a receptor gene expression in the endometrium of women undergoing IVF, and correlate their levels with the IVF pregnancy outcome. Also, the study aimed to detect any sequence mutation in these three genes among IVF pregnant and non-pregnant women versus control menstrual blood of fertile women. Methods: Endometrial tissue biopsies were taken from 15 women undergoing IVF on the day of oocyte retrieval. The quantitative expression of $I L-11, I L-11 R \alpha$ and $L I F$ genes were assessed by real time PCR and PCR products were sequenced by DNA sequencer to detect any DNA sequence changes. Menstrual blood from 10 fertile women was used as control to compare the DNA sequence versus DNA sequence of the studied genes in endometrial biopsies. Luteinizing hormone (LH), follicular stimulating hormone (FSH) and estradiol (E2) were assessed for enrolled patients by ELISA. Endometrial thickness was also assessed by pelvic ultrasonography. Results: No significant difference was detected between quantitative expression of the three studied genes and pregnancy IVF outcome. Although DNA sequence changes were found in IL-11 and LIF genes of women with negative pregnancy IVF outcome compared to women with positive pregnancy IVF outcome. No DNA sequence changes were detected for IL-11R $\alpha$. Other studied parameters (age, LH, FSH, E2 and endometrial thickness) showed no significant differences or correlation with quantitative expression of the three studied involved genes. Conclusions: Data suggested that no significant differences between quantitative expression of IL-11, IL11 Ra and LIF genes and the IVF pregnancy outcome. The present study may reveal that changes in IL-11 and LIF genes sequence may contribute in pregnancy IVF outcome.
\end{abstract}

Key words: gene expression, interleukin-11 (IL-11), interleukin-11 receptor a (IL$11 R \alpha)$, leukemia inhibitory factor (LIF), IVF, DNA sequence 


\section{INTRODUCTION}

Embryo implantation is a
complex process requiring synchronised endometrial receptivity and blastocyst competence ${ }^{(\mathbf{1})}$. The initial apposition, attachment and adhesion of the blastocyst to an adequately prepared or receptive maternal endometrium occur via a coordinated dialogue of locally produced molecules, including cytokines, adhesion and extracellular matrix (ECM) molecules ${ }^{(2)}$.

A class of cytokines, which play an important role in embryonic implantation, is the interleukin-(IL) 6 superfamily. That family consists of numerous cytokines, including leukemia inhibitory factor (LIF), IL-6, interleukin-11 (IL-11), neurotrophic factor, oncostatin-M, and cardiotrophin-1. An important characteristic of that class of cytokines is their sharing of intracellular signaling through gp130 ${ }^{(3)}$. IL-11 and LIF signal via a hetero-dimeric receptor complex comprising either the specific IL-11 receptor $\alpha$ chain or the low-affinity LIF receptor, associated with the common signaling component gp130. Binding of IL-11 or LIF to their receptors forms a complex that signals via activation of Janus kinases (JAKs) which subsequently phosphorylate tyrosine residues in the cytoplasmic domain of the gp130 subunit. This in turn triggers signaling cascades involving mitogen activated protein kinases (MAPKs) and signal transducer and activator of transcription (STAT) family, in particular STAT3 and STAT1 proteins, resulting in the activation of transcription of specific genes ${ }^{(4,5)}$.

During the secretory phase of the menstrual cycle, human endometrial stromal cells spontaneously differentiate into decidualized stromal cells which are morphologically and biochemically distinct. If pregnancy ensues, decidualization proceeds further and provide the maternally derived component of the placenta. The molecular interactions that regulate the formation, maintenance and remodeling of decidua are poorly understood although many factors are known to be involved ${ }^{(6)}$. IL-11 is absolutely required for decidualization of endometrial stromal cells and blastocyst implantation in mice ${ }^{(7)}$. In humans IL-11 mRNA and protein are expressed in the endometrium throughout the menstrual cycle, while its expression in the stroma was reported to be restricted to the predecidualized stromal cells in the late secretory phase to help the blastocyst implantation. The expression of IL-11 and its receptor (IL-11R $\alpha$ ) was found to be maximal during decidualization, suggesting that their interactions in the decidua are important in that process ${ }^{(3,6)}$.

Leukemia inhibitory factor (LIF) derived its name from its ability to induce the terminal differentiation of myeloid leukemia cells, thus preventing their continued growth. One of the main properties attributed to LIF is the regulation of embryo implantation. LIF had been shown to facilitate implantation in the mouse model and possibly in humans ${ }^{(\mathbf{8})}$. LIF is expressed in the luminal epithelium during the mid-late secretory phase 
(days 18-28) of the menstrual cycle, supporting a role in implantation ${ }^{(9)}$. It has been suggested that recombinant human LIF might help to improve the implantation rate in women with unexplained infertility ${ }^{(\mathbf{1 0})}$.

Many in-vitro fertilization (IVF) studies using gene-matrix technology had revealed some differences in the expression of many molecules, cytokines and other factors in endometrium of infertile women compared with fertile women ${ }^{\mathbf{1 1}, \mathbf{1 2})}$.

The aim of the present study was to assess the levels of LIF, IL-11 and IL-11 $\alpha$ receptor gene expression in the endometrium of women undergoing IVF, and correlate their levels with the IVF pregnancy outcome. Also, the study aimed to detect any sequence mutation in these three genes among IVF pregnant and non-pregnant women versus control menstrual blood of fertile women.

\section{PATIENTS AND METHODS}

\section{Patients:}

Fifteen women were enrolled in the current study; they were under IVF long protocol in The IVF Centre, Kasr El Aini Hospital, Cairo University, Egypt. Patients fulfilled the inclusion criteria that included: age between 23 and 35 years, FSH $<10 \mathrm{mIU} / \mathrm{ml}$, no endometriosis, no previous uterine operations, no history of poor response in previous IVF cycles, no diabetes mellitus and antral follicle count $(\mathrm{AFC})>5$. All patients gave their written informed consent to participate in the study.

Tissues:

Endometrial tissue samples were taken on the day of oocyte retrieval using soft suction plastic catheter. The menstrual blood of 10 women with regular menstrual cycles and with no apparent endometrial dysfunction was taken as control samples. The study protocol and informed consents were approved by the Human Ethics Committee of Cairo University.

\section{Total RNA isolation:}

Endometrial biopsies and menstrual control blood were lysed by RLT buffer (QIAGEN, Germantown, MD). The lysates were further prepared for total RNA extraction using the RNeasy mini kit (QIAGEN, Germantown, MD) according to the manufacturer's instructions. The RNA extract was stored at $-80{ }^{\circ} \mathrm{C}$ until future use. RNA purity, yield, and concentration was determined through dual spectrophotometry (Beckman, USA), and $1 \mu \mathrm{g}$ of RNA was run on a $1 \%$ agarose gel (Roche, Castle Hill, Australia) to ensure integrity of the RNA.

Quantitative RT-PCR (qRT-PCR):

Reverse transcriptase (RT) reaction mixture using High Capacity Reverse Transcriptase kit (Applied Biosystems, USA) containing: $1 \mu \mathrm{g}$ total RNA from each sample for cDNA synthesis, $0.5 \mu \mathrm{g}$ random primer, $5 \times \mathrm{RT}$ buffer, $2.5 \mathrm{mmol} / \mathrm{L}$ dNTP, 20 U RNase inhibitor and 200 U MMLV reverse transcriptase in a total volume of $25 \mu \mathrm{l}$ was incubated at $37^{\circ} \mathrm{C}$ for 60 minutes, then heated to 95 ${ }^{\circ} \mathrm{C}$ for 5 minutes to inactivate MMLV. RT was followed by qPCR, $50 \mathrm{ng}$ of cDNA were added to $5 \mathrm{X}$ Fast-Start SYBR green master mix with Rox (Roche Diagnostics, Indianapolis, IN) and $200 \mathrm{ng}$ of primer mix (Sigma). The reaction was carried out in micro optical plates (Applied Biosystems, 
USA) and analyzed using StepOne real-time PCR system (Applied Biosystems, USA). The PCR running method was as follows: 10 minutes at $95^{\circ} \mathrm{C}$ for enzyme activation followed by 40 cycles of 15 seconds at $95^{\circ} \mathrm{C}, 20$ seconds at $55^{\circ} \mathrm{C}$ and 30 second at $72^{\circ} \mathrm{C}$ for the amplification step. The primers used in the qRT-PCR evaluation were specific for target genes (table 1). Relative mRNA expression was calculated by the comparative cycle threshold method $(\Delta \Delta \mathrm{Ct}) \quad$ as outlined in the manufacturer's user manual with GAPDH house-keeping gene. The fluorescence was plotted versus PCR cycle number for reaction and each sample was indicated.

Table (1): The oligonucleotide primers sequence of the studied genes

\begin{tabular}{|l|l|l|l|}
\hline Gene & Primer sequence & $\begin{array}{l}\text { PCR } \\
\text { product }\end{array}$ & $\begin{array}{l}\text { Gene Accession } \\
\text { number }\end{array}$ \\
\hline IL-11 & $\begin{array}{l}\text { Forward: 5'-TCTCTCCTGGCGGACACG-3' } \\
\text { Reverse: 5'-AATCCAGGTTGTGGTCCCC-3' }\end{array}$ & 178 bp & NT_011109.16 \\
\hline IL-11Ra & $\begin{array}{l}\text { Forward: 5'-CACACCCTCGGCTACTTGAT-3' } \\
\text { Reverse: 5'-AAGAAAGGATTCCCAAAGACG-3' }\end{array}$ & $73 \mathrm{bp}$ & NT_008413.18 \\
\hline LIF & $\begin{array}{l}\text { Forward: 5'-TGGTTCTGCACTGGAAACATG-3' } \\
\text { Reverse: 5'-GTAATAGAGAATAAAGAGGGCATTGG-3' }\end{array}$ & 154 bp & NT_011520.12 \\
\hline GAPDH & $\begin{array}{l}\text { Forward: 5'-CCTCTACTGGCGCTGCCAAGGCT-3' } \\
\text { Reverse: 5'-GTCCACCACTGACACGTTGG-3' }\end{array}$ & 246 bp & NT_009759.16 \\
\hline
\end{tabular}

Serum hormonal levels assay:

FSH, LH and $\mathrm{E}_{2}$ were estimated by ELISA according to instructions of manufacturers.

DNA purification and sequencing analysis:

IL-11 and LIF genes were analyzed by direct sequencing of the PCR products using SEQr kit (Applied Biosystems, USA), according to manufacturer's protocol. PCR products were purified using the QIAquick Gel Extraction Kit (QIAGEN). The relevant purified DNA samples of all the cases and controls were amplified and sequenced using automated sequencing with the aid of a Big Dye Terminator Sequencing Kit (PE/Applied Biosystems, Foster City, $\mathrm{CA})$. The samples were run in an automated sequencer ABI Prism 310 Avant (PE/Applied Biosystems). All samples were sequenced twice to ensure the results.

\section{Statistical analysis:}

Data were statistically described in terms of mean \pm standard deviation ( \pm SD). Comparison between women who could achieve pregnancy and those who didn't was done using Mann Whitney $U$ test for independent samples. Correlation between various variables was done using Spearman rank correlation equation. $P$ values $<0.05$ was considered statistically significant. All statistical calculations were done using computer programs SPSS (Statistical Package for the Social Science; SPSS Inc., Chicago, IL, USA) version 15 for Microsoft Windows. 


\section{RESULTS}

Table (2): Demographic and Biochemical characteristics of patients with IVF negative and positive pregnancy outcome

\begin{tabular}{|c|c|c|c|c|c|c|c|c|c|}
\hline $\begin{array}{l}\text { Pregnancy } \\
\text { status }\end{array}$ & & $\begin{array}{l}\text { Age } \\
\text { Years }\end{array}$ & $\begin{array}{l}\text { FSH } \\
\mathrm{mIU} / \mathrm{ml}\end{array}$ & $\begin{array}{l}\mathbf{L H} \\
\mathrm{mIU} / \mathrm{ml}\end{array}$ & $\begin{array}{l}\mathbf{E 2} \\
\mathrm{pg} / \mathrm{ml}\end{array}$ & $\begin{array}{l}\text { End. } \\
\text { Thickness } \\
\text { mm }\end{array}$ & IL-11 & $\begin{array}{l}\text { IL-11 } \\
\text { Ro }\end{array}$ & LIF \\
\hline \multirow{4}{*}{$\begin{array}{l}\text { Negative } \\
\text { IVF Pregnancy } \\
\text { Outcome }(n=10)\end{array}$} & Mean & 29.00 & 5.51 & 5.74 & 52.09 & 12.40 & 12.54 & 9.72 & 12.26 \\
\hline & SD & 3.96 & 1.347 & 4.53 & 8.90 & 1.57 & 0.85 & 0.83 & 1.00 \\
\hline & Min. & 23 & 3.8 & 1 & 44 & 10 & 11.4 & 8.7 & 10.6 \\
\hline & Max. & 35 & 7.0 & 15 & 67 & 15 & 13.9 & 11.2 & 13.3 \\
\hline \multirow{4}{*}{$\begin{array}{l}\text { Positive } \\
\text { IVF Pregnancy } \\
\text { Outcome }(n=5)\end{array}$} & Mean & 30.00 & 5.77 & 3.78 & 46.67 & 11.00 & 12.72 & 9.94 & 11.52 \\
\hline & SD & 4.35 & 2.81 & 1.46 & 15.04 & 1.41 & 0.59 & 0.98 & 0.81 \\
\hline & Min. & 27 & 3.4 & 2 & 31 & 9 & 11.8 & 8.6 & 10.5 \\
\hline & Max. & 35 & 9.4 & 6 & 61 & 13 & 13.3 & 11.1 & 12.4 \\
\hline \multicolumn{2}{|l|}{ p value } & 0.53 & 0.70 & 0.45 & 0.56 & 0.11 & 0.66 & 0.53 & 0.14 \\
\hline
\end{tabular}

FSH: Follicular stimulating hormone, LH: Luteinizing hormone, E2: Estradiol and

End. Thickness: Endometrial thickness. $p$ value: indicates significant value when < 0.05

Table (3) revealed that no statistical significant difference was detected between cases with IVF positive or negative pregnancy outcome for demographic data, hormonal levels and the studied cytokines levels.

Table (3): correlation between quantitative expressions of the three studied genes (IL-11, IL-11 Ro and LIF) and other different parameters

\begin{tabular}{|c|c|c|c|c|}
\hline & Correlation & IL-11 & IL-11 Ra & LIF \\
\hline \multirow[t]{3}{*}{$\overline{\text { Age }}$} & $\mathrm{r}$ & -0.307 & 0.174 & -0.147 \\
\hline & $\mathrm{p}$ value & 0.358 & 0.608 & 0.665 \\
\hline & $\mathrm{N}$ & 15 & 15 & 15 \\
\hline \multirow[t]{3}{*}{$\overline{\text { FSH }}$} & $\mathrm{r}$ & -0.127 & -0.528 & 0.132 \\
\hline & $\mathrm{p}$ value & 0.709 & 0.095 & 0.698 \\
\hline & $\mathrm{N}$ & 15 & 15 & 15 \\
\hline \multirow[t]{3}{*}{$\overline{\mathbf{L H}}$} & $\mathrm{r}$ & -0.182 & -0.323 & 0.151 \\
\hline & $\mathrm{p}$ value & 0.593 & 0.332 & 0.658 \\
\hline & $\mathrm{N}$ & 15 & 15 & 15 \\
\hline \multirow[t]{3}{*}{$\overline{E 2}$} & $r$ & 0.224 & 0.164 & 0.322 \\
\hline & $\mathrm{p}$ value & 0.533 & 0.650 & 0.364 \\
\hline & $\mathrm{N}$ & 15 & 15 & 15 \\
\hline \multirow{3}{*}{$\begin{array}{l}\text { End. } \\
\text { Thickness }\end{array}$} & $\mathrm{r}$ & -0.260 & 0.086 & 0.409 \\
\hline & $\mathrm{p}$ value & 0.349 & 0.760 & 0.130 \\
\hline & $\mathrm{N}$ & 15 & 15 & 15 \\
\hline
\end{tabular}

There was no statistical significant correlation between levels of IL11, IL-11R $\alpha$, and LIF gene expression and other data as age, FSH, LH, E2 and endometrial thickness. 


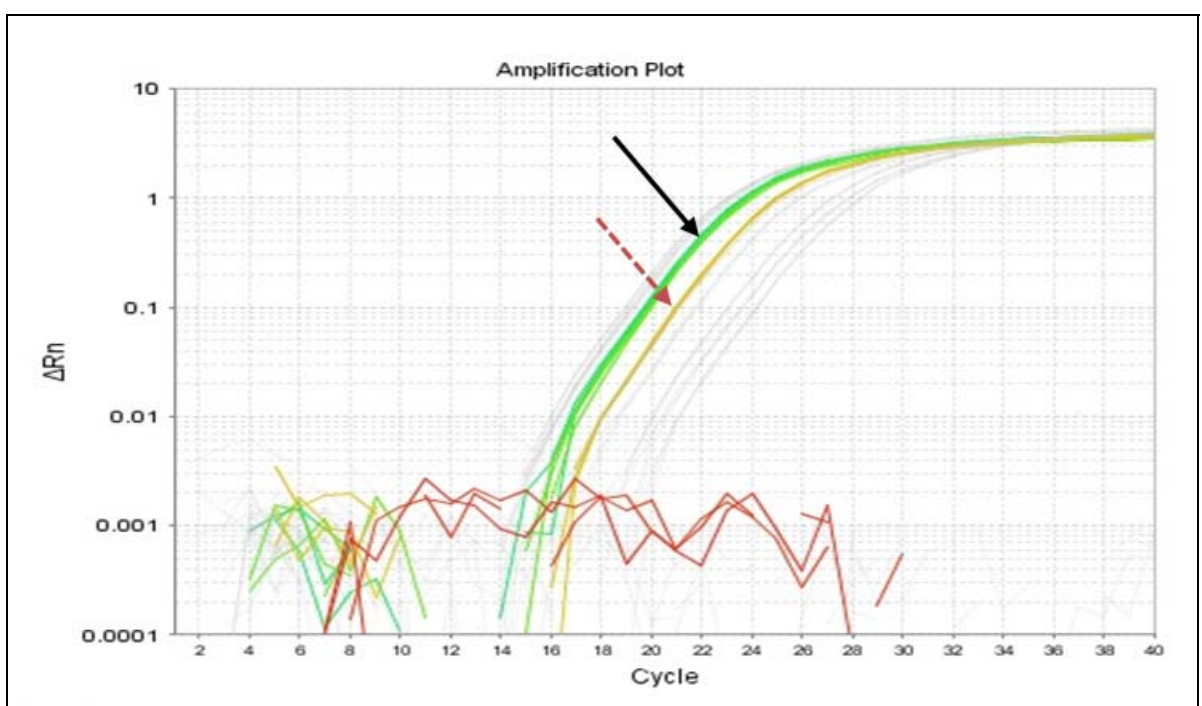

Figure (1): Amplification plot curve measuring LIF (straight arrow) concentration in relation to GAPDH (dotted arrow) as an internal control housekeeping gene

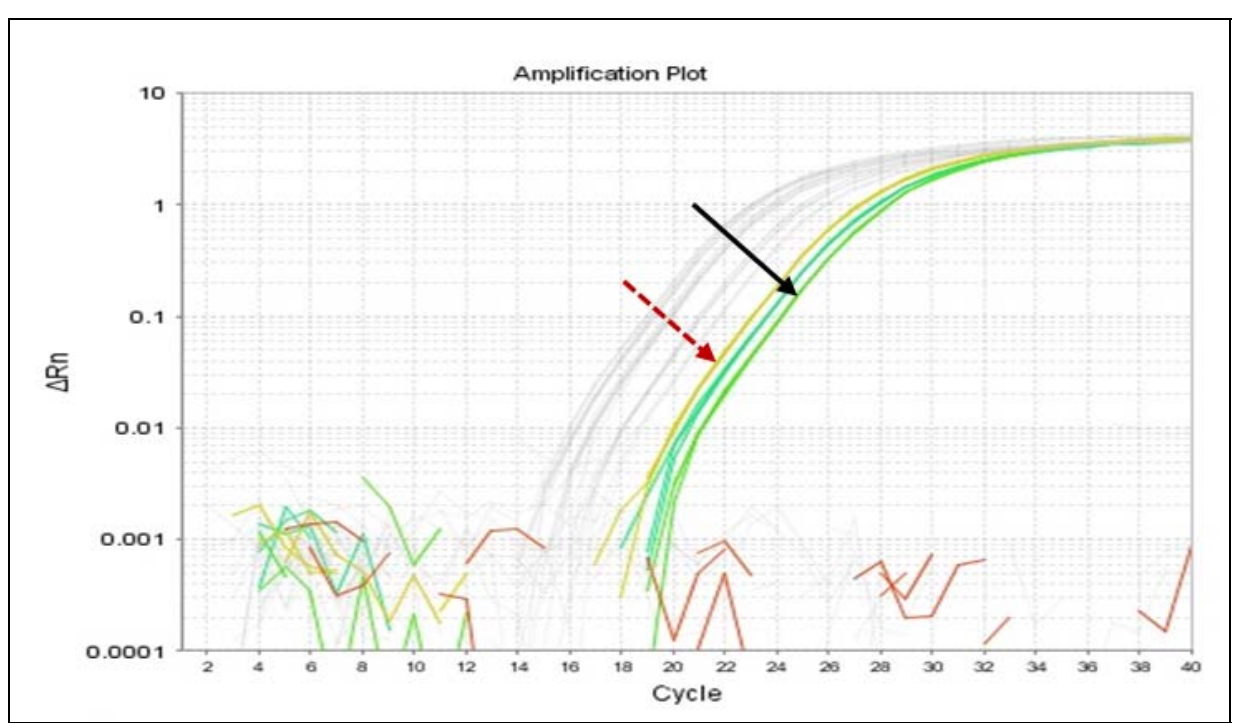

Figure (2): Amplification plot curve measuring IL-11Ra (straight arrow) concentration in relation to GAPDH (dotted arrow) as an internal control housekeeping gene 


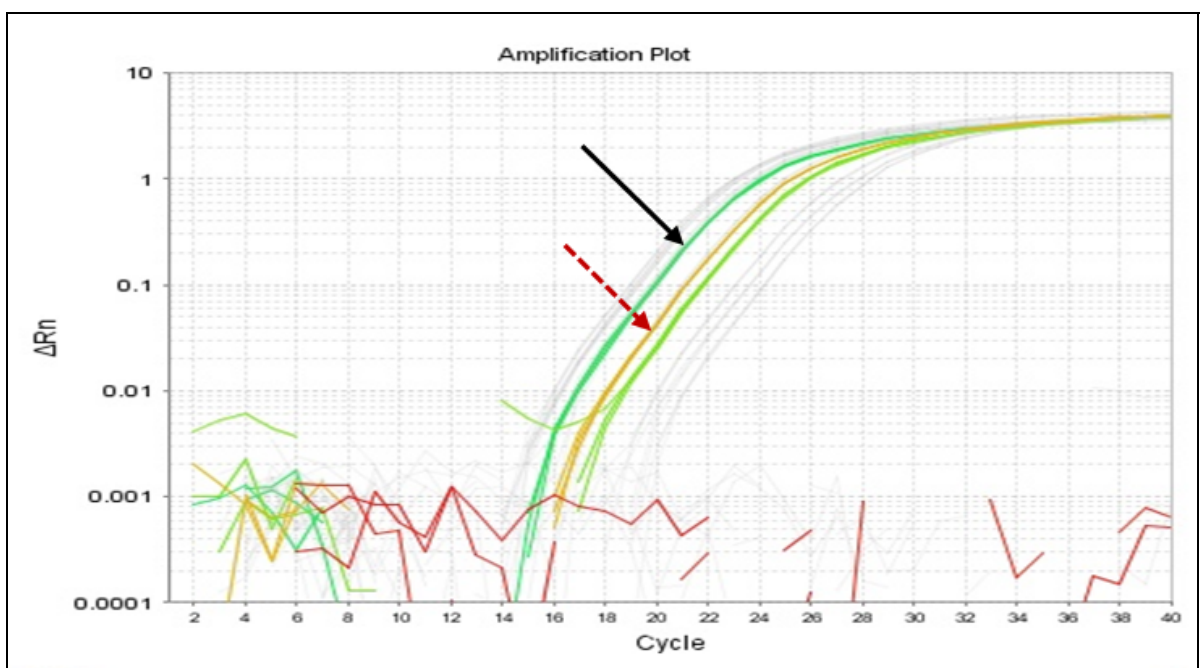

Figure (3): Amplification plot curve measuring IL-11 (straight arrow) concentration in relation to GAPDH (dotted arrow) as an internal control housekeeping gene

DNA sequence analysis results:

Blind DNA sequencing for PCR products of IL-11and LIF was done in order to find possible DNA sequence changes that allow occurrence of pregnancy or not. There was DNA sequence transition from $G$ (at IVF positive pregnancy cases) to T (at IVF negative pregnancy cases) at nucleotide 365 for IL-11 gene (figure 4) and transition from $\mathrm{C}$ (at IVF positive pregnancy cases) to $\mathrm{T}$ (at IVF negative pregnancy cases) at nucleotide 351 for LIF gene (figure 5). These sequence changes was compared to DNA sequence of studied genes in control menstrual blood of fertile women and they were similar to DNA sequences of IVF positive pregnancy cases. No DNA sequence change was detected for IL$11 \mathrm{R} \alpha$ gene at both IVF positive and negative pregnancy cases. 




Figure (4): DNA sequence analysis for IL-11 gene showed $G$ to $T$ transition at nucleotide- 365

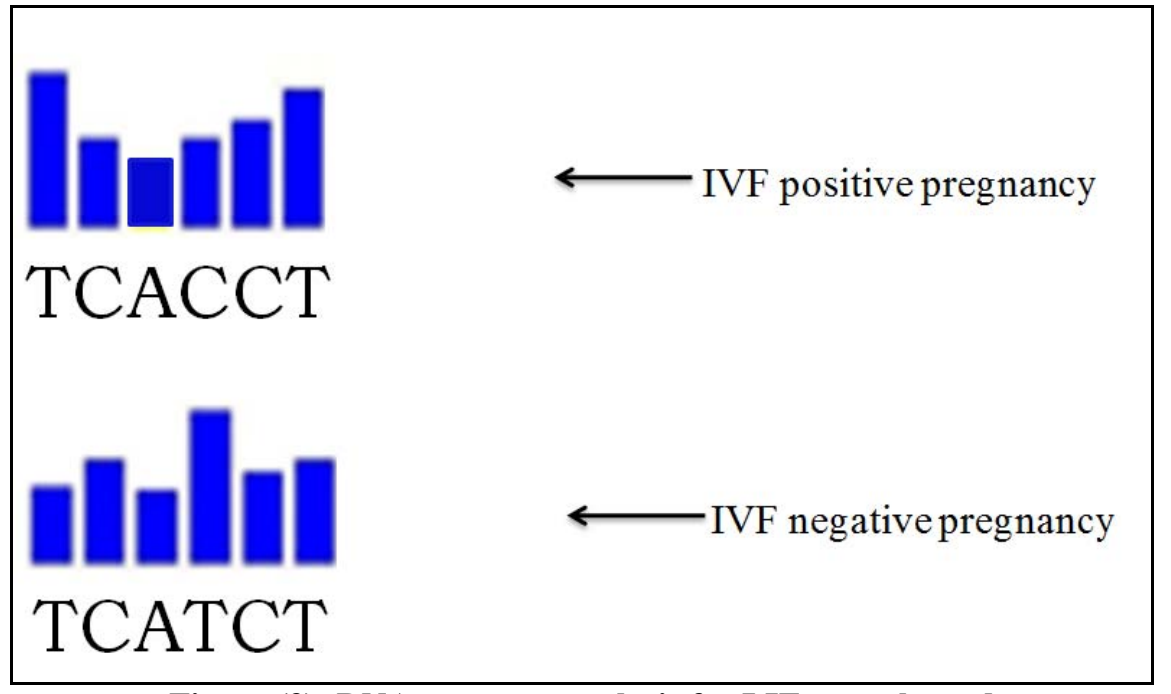

Figure (3): DNA sequence analysis for LIF gene showed $C$ to $T$ transition at nucleotide- 351 
Table (4): DNA sequence changes of IL-11 and LIF PCR products of all studied groups (patients and controls)

\begin{tabular}{|l|l|l|}
\hline No. & IVF outcome & $\begin{array}{l}\text { DNA sequence of } \\
\text { IL-11 and LIF }\end{array}$ \\
\hline 1 & No pregnancy & Sequence change \\
\hline 2 & No pregnancy & Sequence change \\
\hline 3 & No pregnancy & Sequence change \\
\hline 4 & No pregnancy & Sequence change \\
\hline 5 & No pregnancy & Sequence change \\
\hline 6 & No pregnancy & Sequence change \\
\hline 7 & Pregnancy & No Sequence change \\
\hline 8 & Pregnancy & No Sequence change \\
\hline 9 & Pregnancy & No Sequence change \\
\hline 10 & No pregnancy & Sequence change \\
\hline 11 & Pregnancy & No Sequence change \\
\hline 12 & No pregnancy & Sequence change \\
\hline 13 & No pregnancy & Sequence change \\
\hline 14 & No pregnancy & Sequence change \\
\hline 15 & Pregnancy & No Sequence change \\
\hline $\begin{array}{c}\text { Control } \\
\text { menstrual blood }\end{array}$ & & $\begin{array}{l}\text { No sequence change compared to } \\
\text { pregnancy IVF outcome }\end{array}$ \\
\hline
\end{tabular}

Results in table (4) revealed that there were changes in both IL-11 and LIF gene sequence in some patients which may contribute to the pregnancy IVF outcome. Patients with changes in their genes sequence showed failed pregnancy IVF outcome, while patients with no change in the normal sequence, as compared to the controls, showed successful pregnancy IVF outcome.

\section{DISCUSSION}

Implantation is a complex process, in which the foreign blastocyst needs to be accepted by the maternal endometrium. To allow for that, extensive preparation and bidirectional communication between the blastocyst and the endometrium are required ${ }^{(\mathbf{9})}$. Implantation process encompasses several distinct stages: apposition, adhesion, penetration, and trophoblast invasion. These steps can only take place during the window of implantation ${ }^{(13)}$.

In human in vitro fertilization (IVF), embryo transfer can be accompanied by a low implantation rate even after a very successful IVF. The continuous tendency of improving implantation rates is of prime importance. The economic problems and psychological constraints linked to the necessity of undergoing multiple attempts before obtaining a successful pregnancy are a continuous worry for both medical practitioners and economists. Further specific and detailed knowledge about the molecules network that control 
proper implantation are needed to be known in such a perspective.

Many molecules play important roles in the events of implantation such as; adhesion molecules, chemokines, cytokines, growth factors, and invasive proteinases ${ }^{(\mathbf{1 4})}$. Both, interleukin 11 (IL-11) and leukemia inhibitory factor (LIF) are two of few cytokines known to be absolutely required for blastocyst implantation, and both are obligatory for implantation in mice ${ }^{(7)}$.

In the current study we confirmed, by using quantitative RTPCR, that there were no significant differences among gene expression levels of LIF, IL-11 and IL-11R $\alpha$ between implantation versus nonimplantation IVF.

In agreement with our results, Gazvani et al. ${ }^{(15)}$ reported that no significant difference in IL-11 mRNA expression pattern in the peritoneal fluid and the endometrium of fertile and infertile women.

Additional confirmation to our results was added by Mikolajczyk et al. ${ }^{(12)}$, who showed no statistically significant differences in uterine flushing in infertile women (with and without endometriosis) with regard to IL-11 and LIF levels when compared to fertile controls.

However, the present results disagree with those reported by Lédée et al. $^{(16)}$ and Dimitriadis et al. ${ }^{(6,17)}$, who concluded that LIF, IL-11 and IL-11R $\alpha$ mRNA and protein are down regulated in the endometrium of women with unexplained/ idiopathic infertility or infertility and endometriosis compared with that of fertile controls.
Also, reduced IL-11 and LIF secretion by endometrial epithelial cells may be responsible for the reduced implantation/ pregnancy rates in excessive ovarian responders during IVF treatment ${ }^{(\mathbf{1 8 , 1 9})}$.

This contradiction between results may be reasonably explained due to the different techniques used, the different timing for endometrial sampling, or the number of patients included in each study.

In the present study, changes in the sequences of IL-11 and LIF DNA were detected at failed IVF pregnancy outcome compared to DNA sequence for both genes of successful IVF pregnancy outcome. While in IL$11 \mathrm{R} \alpha$ no DNA sequence changes were detected at both failed and successful IFV pregnancy outcomes.

Female mice with a null mutation of the IL-11 are infertile due to a defective post-implantation response to the implanting blastocyst, whereas female mice with no functional LIF gene are infertile due to an inability of normal embryos to implant ${ }^{(7,20)}$.

Mutation of LIF gene results in reproductive failure in LIF -/- mice due to an inability to implant their blastocysts. That condition is reversed by infusion of LIF or by transfer of embryos to pseudo-pregnant recipient of wild-type mice ${ }^{(21)}$. Kralickova et al. ${ }^{\text {(22) }}$ investigated the prevalence of the LIF gene mutations in the population of infertile women that consisted of nulligravid and secondary infertile patients. They revealed that the frequency of functionally relevant mutations of the LIF gene in infertile women is significantly enhanced in comparison with fertile controls. 
Certain studies suggested that LIF gene mutations contribute to embryo implantation failure and thus to infertility and decreased pregnancy rates in Assisted Reproductive Technology $(\text { ART })^{(\mathbf{2 2 , 2 3})}$. These results coincided with our suggestion that the LIF gene mutations affect fertility.

The current study is just a pilot study and a larger number of infertile patients to be compared with fertile women are needed for further investigations. Also, complete and detailed understanding of the complex regulatory mechanisms may provide new therapeutic targets for female infertility.

\section{REFERENCES}

1. Salamonsen L. A., Nie G., Hannan N. J. and Dimitriadis E. (2009): Preparing fertile soil: the importance of endometrial receptivity. Reprod. Fertil. Dev.; 21(7): 923-934.

2. Sharkey A. M. and Smith S. K. (2003): The endometrium as a cause of implantation failure. Best Pract. Res. Clin. Obstet. Gynaecol.; 17(2): 289-307.

3. Cork B. A., Tuckerman E. M., Li T. C., Laird S. M. (2002): Expression of interleukin (IL)-11 receptor by the human endometrium in vivo and effects of IL-11, IL-6 and LIF on the production of MMP and cytokines by human endometrial cells in vitro. Mol. Hum. Reprod.; 8(9): 841-848.

4. Cheng J. G., Chen J. R., Hernandez L., Alvord W. G. and Stewart C. L. (2001): Dual control of LIF expression and LIF receptor function regulate STAT3 activation at the onset of uterine receptivity and embryo implantation. Proc. Natl. Acad. Sci.; 98(15): 8680-8685.

5. Dimitriadis E., White C. A., Jones R. and Salamonsen L.A. (2005): Cytokines, chemokines and growth factors in endometrium related to implantation. Hum. Reprod.; 11(6): 613-630.

6. Dimitriadis E., Stoikos C., Stafford-Bell M., Clark I., Paiva P. and Kovacs G. (2006): Interleukin-11, IL-11 receptor alpha and leukemia inhibitory factor are dysregulated in endometrium of infertile women with endometriosis during the implantation window. J. Reprod. Immunol.; 69(1): 53-64.

7. Robb L., Li R., Hartley L., Nandurkar H. H., Koentgen F. and Begley C. G. (1998): Infertility in female mice lacking the receptor for interleukin 11 is due to a defective uterine response to implantation. Nat. Med.; 4(3): 303-308.

8. Hu W., Feng Z., Teresky A. K. and Levine A. J. (2007): p53 regulates maternal reproduction through LIF. Nature; 450(7170): 721-724.

9. Van Mourik M. S., Macklon N. S. and Heijnen C. J. (2009): Embryonic implantation: cytokines, adhesion molecules, and immune cells in establishing an implantation environment. J. Leukoc. Biol.; 85(1): 4-19.

10. Aghajanova L. (2004): Leukemia inhibitory factor and human embryo implantation. 
Annals. of the New York Academy of Sciences; 1034: 176-183.

11. Giudice L. C., Telles T. L., Lobo S. and Kao L. (2002): The molecular basis for implantation failure in endometriosis, on the road to discovery. Ann. NY. Acad. Sci.; 955: 252-264.

12. Mikolajczyk M., Wirstlein P. and Skrzypczak J. (2006): Leukemia inhibitory factor and interleukin 11 levels in uterine flushing of infertile patients with endometriosis. Human Reproduction; 21(12): 30543058.

13. Jabbour H. N., Kelly R. W., Fraser H. M. and Critchley $H$. Q. (2006): Endocrine regulation of menstruation. Endocr. Rev.; 27(1): 17-46.

14. Karpovich N., Chobotova K., Carver J., Heath J. K., Barlow D. H. and Mardon H. J. (2003): Expression and function of interleukin-11 and its receptor $\alpha$ in the human endometrium. Mol. Hum. Reprod.; 9(2): 75-80.

15. Gazvani M. R., Bates M., Vince G., Christmas S., Lewis-Jones I. D. and Kingsland C. (2000): Peritoneal fluid concentrations of interleukin-11 in women with endometriosis. Fertil. Steril.; 74(6): 1182-1186.

16. Lédée-Bataille $N$, LapréeDelage G, Taupin JL, Dubanchet S, Frydman R, Chaouat G. (2000): Concentration of leukemia inhibitory factor (LIF) in uterine flushing fluid is highly predictive of embryo implantation. Hum. Reprod.; 17(1): 213-218.
17. Dimitriadis E., Sharkey A. M., Tan Y., Salamonsen L. A. and Sherwin J. R. (2007): Immunolocalization of phosphorylated STAT3, interleukin 11 and leukaemia inhibitory factor in endometrium of women with unexplained infertility during the implantation window. Reprod. Biol. Endocrinol.; 5 (44):1-8.

18. Menkhorst E., Salamonsen L., Robb L., and Dimitriadis E. (2009): IL-11 antagonist inhibits uterine stromal differentiation, causing pregnancy failure in Mice. Biol. Reprod. ; 80(5): 920927.

19. Yap J., Foo C. F., Lee M. Y., Stanton P. G. and Dimitriadis E. (2011): Proteomic analysis identifies interleukin 11 regulated plasma membrane proteins in human endometrial epithelial cells in vitro. Reproductive Biology and Endocrinology; 9:73.

20. Marwood M., Visser K., Salamonsen L. A. and Dimitriadis E. (2009): Interleukin-11 and leukemia inhibitory factor regulate the adhesion of endometrial epithelial cells: Implications in fertility regulation. Endocrinology; 150(6): 2915-2923.

21. Hirzel D. J., Wang J., Das S. K., Dey S. K. and Mead R. A. (1999): Changes in uterine expression of leukemia inhibitory factor during pregnancy in the western spotted skunk. Biology of Reproduction; 60(2): 484-492.

22. Kralickova M., Sima R., Vanecek T., Sima P., Rokyta Z., Ulcova-Gallova Z., Sucha R., Uher P. and Hes O. (2006): 
Leukemia inhibitory factor gene mutations in the population of infertile women are not restricted to nulligravid patients. Eur $\mathrm{J}$ Obstet Gynecol Reprod Biol.; 127(2): 231-235.

23. Steck T., Giess R., Suetterlin M. W., Bolland M., Wiest S.,
Poehls U. G. and Dietl J. (2004):

Leukemia inhibitory factor (LIF) gene mutations in women with unexplained infertility and recurrent failure of implantation after IVF and embryo transfer. Eur. J. Obstet. Gynecol. Reprod. Biol.; 112(1): 69-73. 


\title{
دراسة تجريبية على الكم والتسلسل الجزيئي للتعبير الجيني لسيتوكينات بطانة الرحم وتأثير هما على نتائج دورة التلقيح الصناعي
}

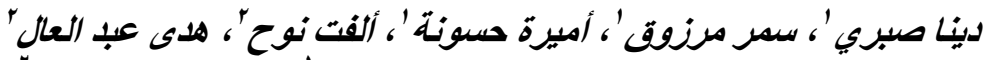

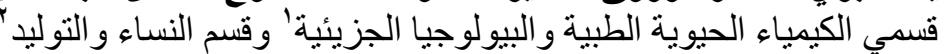 \\ كلية الطب، جامعة القاهرة
}

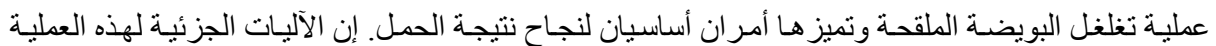

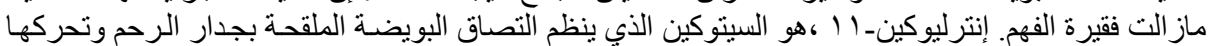

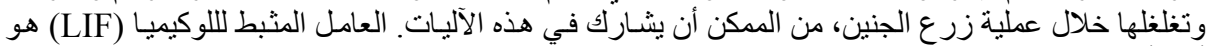

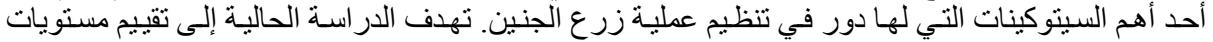

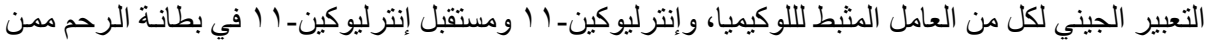

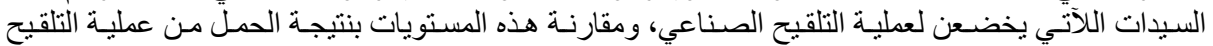



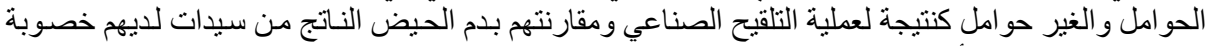



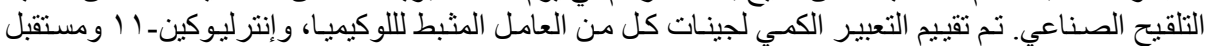

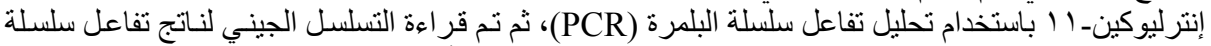

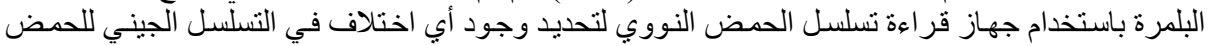

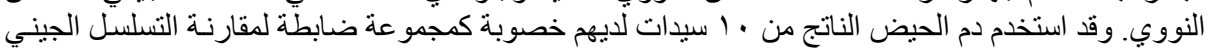

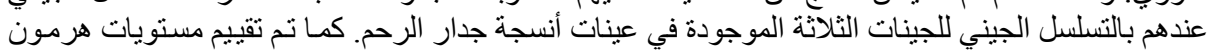

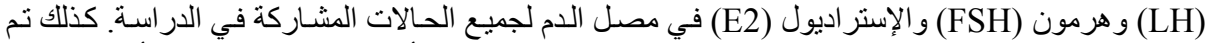

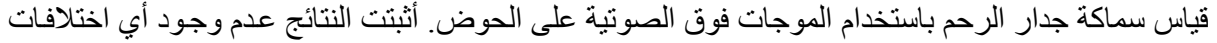

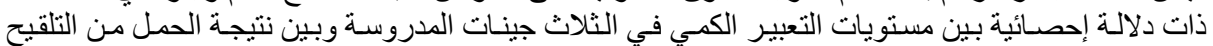

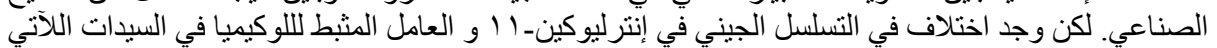

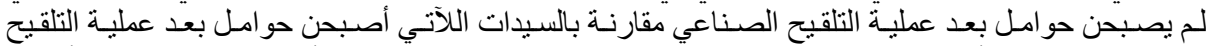

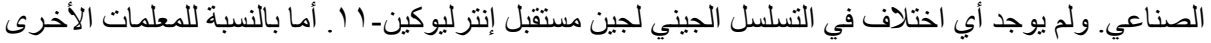



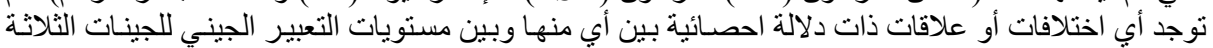

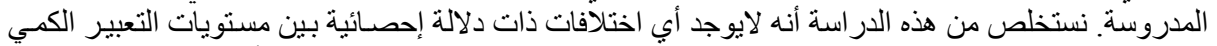

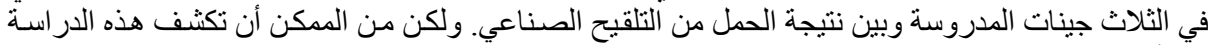

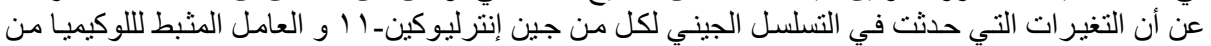
المكن أن يكون لها دور في نتيجة التلقيح الصناعي.
\end{abstract}

